\title{
Studi Eksperimen Pengaruh Tebal Cat dan Kekasaran pada Pelat Baja Karbon Rendah Terhadap Kerekatan Cat dan Biaya Proses di PT. Swadaya Graha \\ Rishad Antony Pratama dan Sudiyono Kromodiharjo \\ Jurusan Teknik Mesin, Fakultas Teknologi Industri, Institut Teknologi Sepuluh Nopember (ITS) \\ Jl. Arief Rahman Hakim, Surabaya 60111 Indonesia \\ e-mail: sudiyono_kromod@me.its.ac.id
}

\begin{abstract}
Abstrak - Keberadaan industri manufaktur di Indonesia sangatlah penting. karena dengan peningkatan kualitas dan kuantitas output yang dihasilkan maka dapat meningkatkan daya saing industri di pasar global. PT. Swadaya Graha merupakan salah satu anak usaha PT. Semen Indonesia (Persero) Tbk. Sejak tahun 1985 PT. Swadaya Graha bergerak dalam bidang manufaktur. Berhubungan dengan proses manufaktur yang ada di PT. Swadaya Graha, proses pengecatan atau coating merupakan proses manufaktur akhir yang dibutuhkan untuk melapisi semua komponen yang dibuat. Perbaikan pada lapisan cat akan memakan waktu yang relatif lama dan memakan biaya sehingga akan memperlambat selesainya suatu komponen. Oleh karena itu Penelitian Tugas Akhir ini akan mengangkat kasus mengenai kekuatan rekat. Eksperimen ini dimaksudkan agar mengetahui pengaruh ketebalan lapisan cat dan tingkat kekasaran permukaan terhadap kekuatan rekat cat pada suatu baja karbon rendah dan mengetahui kombinasi antara ketebalan cat dan kekasaran permukaan manakah yang paling optimal. Kekuatan rekat cat diketahui dari hasil pengujian pull off adhesion. Hasil penelitian yang didapatkan dari pengujian dengan objek pelat baja karbon $250 \times 250 \times 6 \mathrm{~mm}$ menunjukkan bahwa seluruh hasil berada diatas standar. Daya lekat tertinggi yaitu 14.32 MPa dengan kekasaran 30-50 $\mu \mathrm{m}$ dan ketebalan cat $320 \mu \mathrm{m}$ pada klasifikasi C5 (struktur di lingkungan laut). Daya lekat tertinggi pada klasifikasi C4 (industri pengolahan kimia) yaitu 13.85 MPa dengan kekasaran 30-50 $\mu \mathrm{m}$ dan ketebalan $280 \mu \mathrm{m}$. Dan daya lekat tertinggi pada klasifikasi C3 (struktur jembatan) yaitu 13.11 MPa dengan kekasaran 30-50 $\mathrm{mm}$ dan ketebalan $320 \mu \mathrm{m}$. Biaya proses pengecatan termurah pada klasifikasi C3 sebesar Rp. 8.307. Biaya proses pengecatan termurah pada klasifikasi C4 sebesar Rp. 10.908. Sedangkan biaya proses pengecatan termurah pada klasifikasi C5 sebesar Rp. 12.363.
\end{abstract}

Kata Kunci- cat, kekasaran, kekuatan rekat, ketebalan.

\section{PENDAHULUAN}

$\mathrm{K}$ EBERADAAN industri manufaktur di Indonesia sangatlah penting. karena dengan peningkatan kualitas dan kuantitas output yang dihasilkan maka dapat meningkatkan daya saing industri di pasar global. Berdasarkan BPS (Badan Pusat Statistik), sektor industri manufaktur berada pada ranking pertama dalam kontribusinya terhadap pertumbuhan ekonomi nasional. Jika melihat struktur neraca perdagangan Indonesia terakhir, total ekspor untuk tahun 2015 adalah US\$ 14.5 , dimana $84.5 \%$ dari total nilai ekspor disumbang dari pendapatan nonmigas. Dari nilai total ekspor nonmigas, kontribusi terbesar kedua yaitu $13.55 \%$ disumbang dari golongan besi baja, Mesin-mesin dan Otomotif termasuk industri manufaktur didalamnya. Hal ini merupakan bukti bahwa industri manufaktur memainkan peran penting untuk peningkatan ekonomi Indonesia.

PT. Swadaya Graha merupakan salah satu anak usaha PT. Semen Indonesia (Persero) Tbk. Sejak tahun 1985 PT. Swadaya Graha bergerak dalam bidang manufaktur dan jasa konstruksi yaitu dibidang fabrikasi baja, kontraktor sipil, kontraktor mekanikal \& elektrikal, persewaan alat-alat berat. PT. Swadaya Graha saat ini sedang mengembangkan kemampuan dalam merancang, membuat dan menyelesaikan proyek pada PT. Semen Indonesia di Cigading, PT. Gudang Garam di Kediri, PT Wasa Mitra Engineering di Cilegon, PT. Petrokimia di Gresik, dll.

Berhubungan dengan proses manufaktur yang ada di PT. Swadaya Graha, proses pengecatan atau coating merupakan proses manufaktur akhir yang dibutuhkan untuk melapisi semua komponen yang dibuat. Tujuan dari pelapisan cat sendiri untuk meningkatkan penampilan, ketahanan terhadap air, ketahanan dari goresan atau bahkan untuk keausan. Oleh karena itu proses pengecatan ini merupakan salah satu proses yang membutuhkan anggaran dana besar pada pelaksanaanya. Perbaikan pada lapisan cat akan memakan waktu yang relatif lama dan memakan biaya sehingga akan memperlambat selesainya suatu komponen. Salah satu hal yang menentukan hasil pelapisan cat tidak hanya ditentukan oleh jenis cat yang digunakan, tetapi juga oleh parameter aplikasi cat seperti ketebalan lapisan cat dan besarnya nilai kekasaran permukaan substrat yang dihasilkan, faktor kondisi lingkungan dimana substrat ditempatkan dan persiapan permukaan sebelum pelapisan juga perlu diperhatikan. Oleh sebab itu, pada penelitian ini akan di evaluasi pengaruh ketebalan lapisan cat dan tingkat kekasaran terhadap kekuatan rekat cat pada plat baja karbon rendah. Sehingga dapat memberi solusi yang baik untuk mendapatkan kekuatan rekat cat yang optimal. 


\section{METODOLOGI PENELITIAN}

\section{A. Langkah Eksperimen}

Sesuai dengan rumusan maslaha dan tujuan yang disampaikan, adapun langkah penelitian untuk mencapai tujuan tersebut seperti pada diagram alir berikut ini:

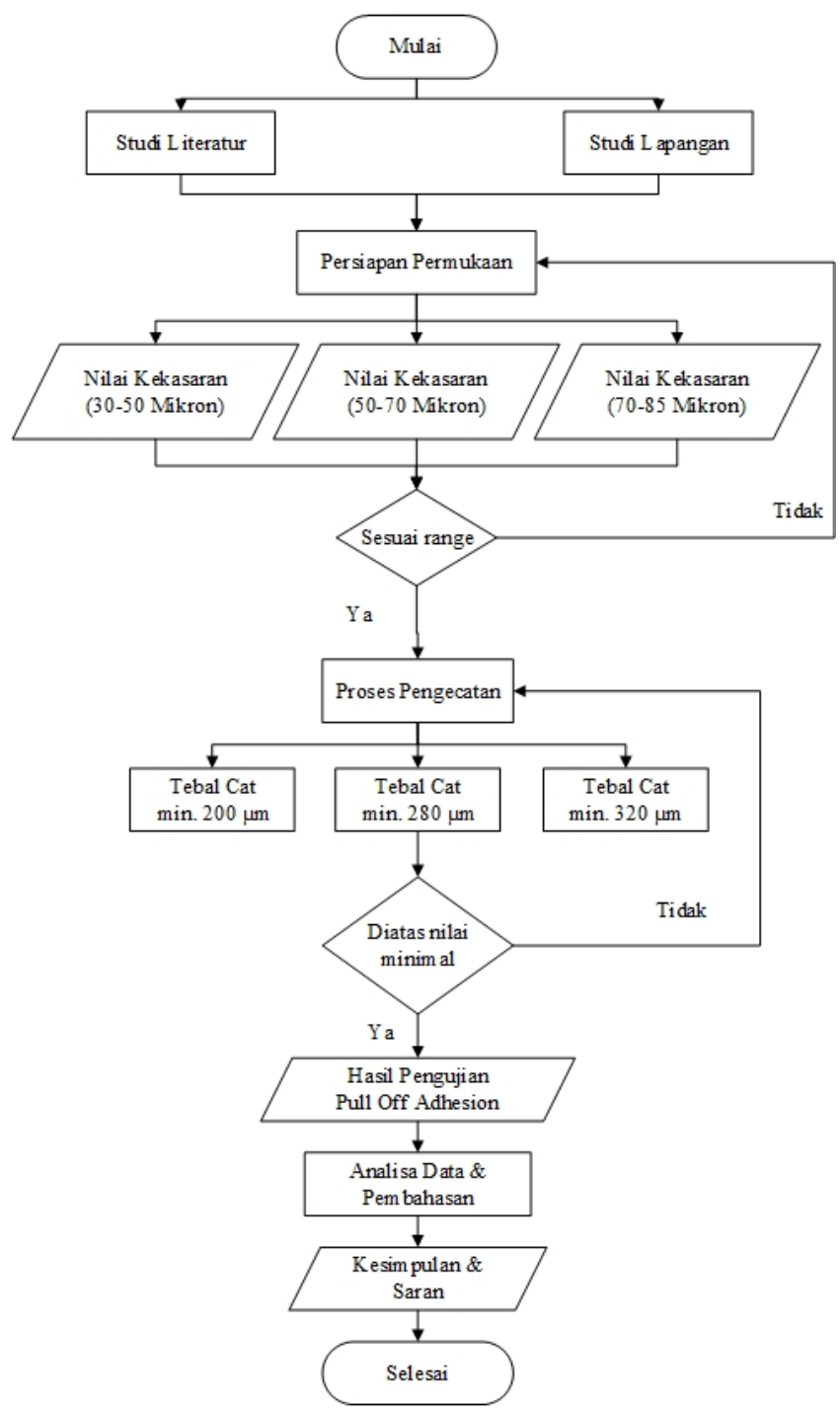

Gambar 1. Diagram Alir penelitian

\section{B. Prosedur Pengujian}

Proses pengecatan adapun langkah-langkah pengujian seperti berikut ini:

1. Preparasi objek dengan memotong plat baja menjadi dimensi $250 \times 250 \times 6 \mathrm{~mm}$ untuk digunakan sebagai spesimen pengujian kekuatan rekat sebanyak 3 buah untuk setiap variabel.

2. Persiapan permukaan dengan membersihkan permukaan dengan sand blasting sampai tingkat kebersihan Sa 2.5 atau SSPC SP-10. Material abrasif yang digunakan adalah pasir silika yang dilakukan rekan satu tim.

3. Persiapan material cat dengan mencampur dan mengaduk cat epoksi sebagai komponen A dengan penambahan curing agent sebagai komponen $\mathrm{B}$ sesuai data sheet pengecatan hempel.

4. Pengaplikasian cat dilakukana seperti diagram alir proses pengecatan berikut ini:

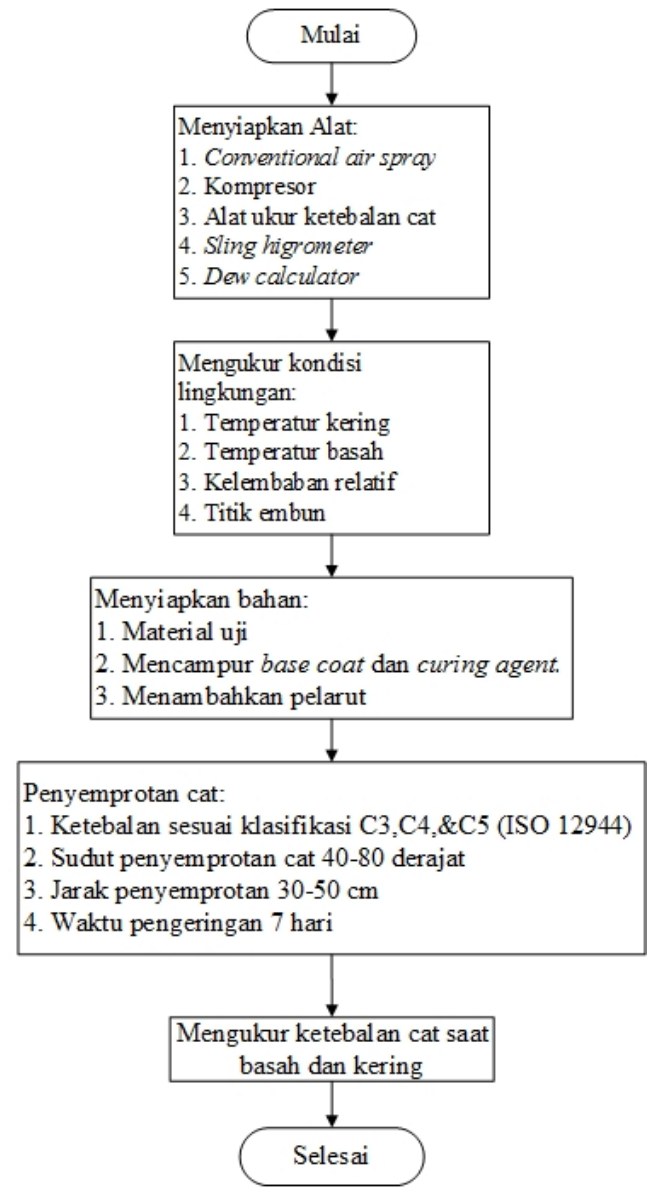

Gambar 2. Diagram Alir pengecatan

5. Melakukan pengujian pull off menggunakan alat Portable Adhesive Tester untuk mengetahui besar kekuatan adhesi lapisan coating terhadap plat berdasarkan standar ASTM D-4541.

\section{Bahan Penelitian}

Bahan yang akan digunakan pada penelitian ini adalah:

1. Pelat baja karbon rendah berukuran $250 \times 250 \times 6 \mathrm{~mm}$.
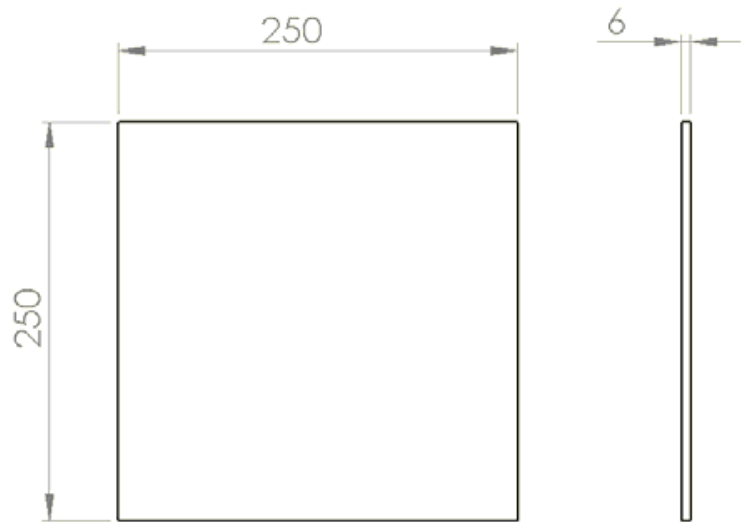

Gambar 3. Dimensi Pelat Baja Karbon Rendah 
2. Cat epoxy dua komponen menggunakan hempadur mastic 45880 merk Hempel. Cat ini terdiri dari komponen utama yaitu epoksi resin dan komponen kedua yang berfungsi untuk mempercepat proses pengeringan cat epoksi tersebut.

3. Cat polyurethane menggunakan hempathane 55210 merk Hempel. Cat ini sebagai pelindung terhadap pengaruh lingkungan selain itu cat akhir berfungsi memberikan warna dan kilap. Biasanya memiliki permukaan yang halus, licin serta mudah dibersihkan.

\section{Rancangan Penelitian}

Penelitian menggunakan tiga level kekasaran dan tiga level ketebalan cat. Dengan pengulangan sebanyak tiga kali. Sehingga terdapat 27 kali pengujian pull off adhesion. Dengan pembuktian metode statistik berupa uji homogenitas varians dan uji analaysis of variance.

\section{HASIL DAN ANALISA}

\section{A. Hasil pengukuran tebal cat epoksi dan polyurethane}

Tabel 1. Hasil pengukuran DFT

\begin{tabular}{ccccccc}
\hline \hline \multirow{2}{*}{$\begin{array}{c}\text { Kekasaran } \\
(\mu \mathrm{m})\end{array}$} & \multicolumn{5}{c}{ Ketebalan DFT $(\mu \mathrm{m})$} \\
& C3 & C4 & C5 & C3 & C4 & C5 \\
\hline \multirow{3}{*}{$30-50$} & 170 & 230 & 232 & 207 & 277 & 308 \\
& 146 & 217 & 242 & 214 & 280 & 318 \\
& 193 & 198 & 224 & 206 & 253 & 289 \\
$50-70$ & 166 & 203 & 229 & 229 & 286 & 302 \\
& 160 & 218 & 234 & 221 & 282 & 331 \\
& 185 & 216 & 242 & 214 & 277 & 323 \\
$70-85$ & 161 & 211 & 246 & 238 & 293 & 326 \\
& 171 & 197 & 241 & 232 & 313 & 327 \\
& 172 & 223 & 251 & 225 & 293 & 335 \\
\hline \hline
\end{tabular}

Tabel 1 menunjukkan hasil pengukuran ketebalan cat saat setelah pengeringan cat epoksi dan saat setelah pengeringan cat epoksi yang telah ditambahakan polyurethane. Proses pengukuran dilakukan sesuai standar ASTM D1005.

\section{B. Biaya Operasional dan Cat}

Tabel 2. Total biaya pengecatan

\begin{tabular}{ccccc}
\hline $\begin{array}{c}\text { Biaya } \\
\text { Operasiona } \\
\text { 1+Cat } \\
(\text { Rupiah })\end{array}$ & $\begin{array}{c}\text { Ketebala } \\
\mathrm{n} \\
(\mu \mathrm{m})\end{array}$ & $\begin{array}{c}\text { Biaya } \\
\text { Kekasara } \\
\mathrm{n} \\
(\text { Rupiah })\end{array}$ & $\begin{array}{c}\text { Kekasara } \\
\mathrm{n} \\
(\mu \mathrm{m})\end{array}$ & $\begin{array}{c}\text { Total } \\
\text { Biaya } \\
(\text { Rupiah }\end{array}$ \\
\hline 4.933 & 200 & 3.394 & $30-50$ & 8.327 \\
4.933 & 200 & 4.034 & $50-70$ & 8.967 \\
4.933 & 200 & 4.674 & $70-85$ & 9.607 \\
7.514 & 280 & 3.394 & $30-50$ & 10.908 \\
7.514 & 280 & 4.034 & $50-70$ & 11.548 \\
7.514 & 280 & 4.674 & $70-85$ & 12.188 \\
8.969 & 320 & 3.394 & $30-50$ & 12.363 \\
8.969 & 320 & 4.034 & $50-70$ & 13.003 \\
8.969 & 320 & 4.674 & $70-85$ & 13.645 \\
\hline \hline
\end{tabular}

Dengan menghasilkan kekasaran antara $\quad 30-50 \quad \mu \mathrm{m}$ memakan biaya adalah Rp. 3.394, kekasaran antara 50-70 $\mu \mathrm{m}$ adalah Rp. 4.034, sedangkan kekasaran antara 70-85 $\mu \mathrm{m}$ adalah Rp. 4.674. Data biaya kekasaran tersebut didapat dari rekan satu tim.

Dari total biaya pengecatan tersebut dapat di representasikan melalui grafik seperti berikut ini:

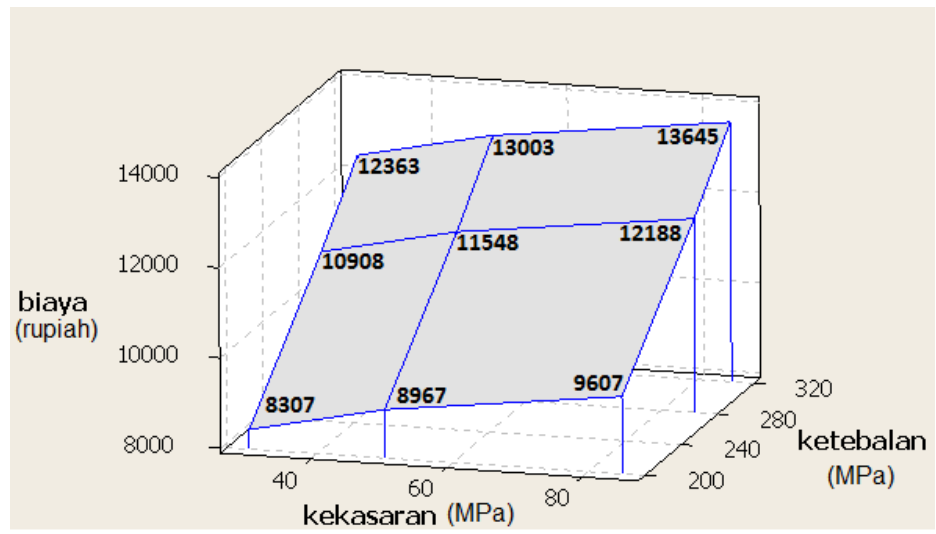

Gambar 1. Grafik 3D total biaya pengecatan

\section{Pengujian Kekuatan adhesi}

Pengujian Kekuatan adhesi pada penelitian ini dilakukan dengan metode pull off adhesion test berdasarkan standar ISO 4642. Dengan standar nilai minimum yang dapat diterima yaitu $5 \mathrm{MPa}$.

\begin{tabular}{ccccc}
\multicolumn{5}{c}{ Tabel 3. Hasil Pengujian Pull Off Adhesion Test C3 } \\
\hline \hline $\begin{array}{c}\text { Tebal } \\
\text { Cat }\end{array}$ & $\begin{array}{c}\text { R } \\
\text { (pengulangan) }\end{array}$ & $30-50 \mu \mathrm{m}$ & $50-70 \mu \mathrm{m}$ & $\begin{array}{c}70-85 \\
\mu \mathrm{m}\end{array}$ \\
\hline Min. & 1 & 14.67 & 13.63 & 11.08 \\
200 & 2 & 12.02 & 11.32 & 10.49 \\
$\mu \mathrm{m}$ & 3 & 12.65 & 10.09 & 9.96 \\
\hline \hline
\end{tabular}

Tabel 4. Hasil Pengujian Pull Off Adhesion Test C4

\begin{tabular}{|c|c|c|c|c|}
\hline \multirow{2}{*}{$\begin{array}{c}\text { Tebal } \\
\text { Cat }\end{array}$} & \multirow{2}{*}{$\begin{array}{c}\mathrm{R} \\
\text { (pengulangan) }\end{array}$} & \multicolumn{3}{|c|}{ Nilai Kekasaran } \\
\hline & & $\begin{array}{c}30-50 \\
\mu \mathrm{m}\end{array}$ & $\begin{array}{c}50-70 \\
\mu \mathrm{m}\end{array}$ & $\begin{array}{c}70-85 \\
\mu \mathrm{m}\end{array}$ \\
\hline \multirow{3}{*}{$\begin{array}{l}\text { Min. } \\
280 \mu \mathrm{m}\end{array}$} & 1 & 12.89 & 12.55 & 10.77 \\
\hline & 2 & 15.10 & 12.62 & 10.56 \\
\hline & 3 & 13.57 & 13.29 & 11.92 \\
\hline \multicolumn{5}{|c|}{ Tabel 5. Hasil Pengujian Pull Off Adhesion Test C5 } \\
\hline \multirow{2}{*}{$\begin{array}{l}\text { Tebal } \\
\text { Cat }\end{array}$} & \multirow{2}{*}{$\begin{array}{c}\mathrm{R} \\
\text { (pengulangan) }\end{array}$} & \multicolumn{3}{|c|}{ Nilai Kekasaran } \\
\hline & & $\begin{array}{c}30-50 \\
\mu \mathrm{m}\end{array}$ & $\begin{array}{c}50-70 \\
\mu \mathrm{m}\end{array}$ & $\begin{array}{c}70-85 \\
\mu \mathrm{m}\end{array}$ \\
\hline \multirow{3}{*}{$\begin{array}{l}\text { Min. } \\
320 \mu \mathrm{m}\end{array}$} & 1 & 15.65 & 14.07 & 12.21 \\
\hline & 2 & 13.11 & 12.74 & 11.66 \\
\hline & 3 & 14.20 & 13.19 & 11.30 \\
\hline
\end{tabular}

Dari hasil pull off adhesion test tersebut dapat di representasikan melalui grafik seperti berikut, 


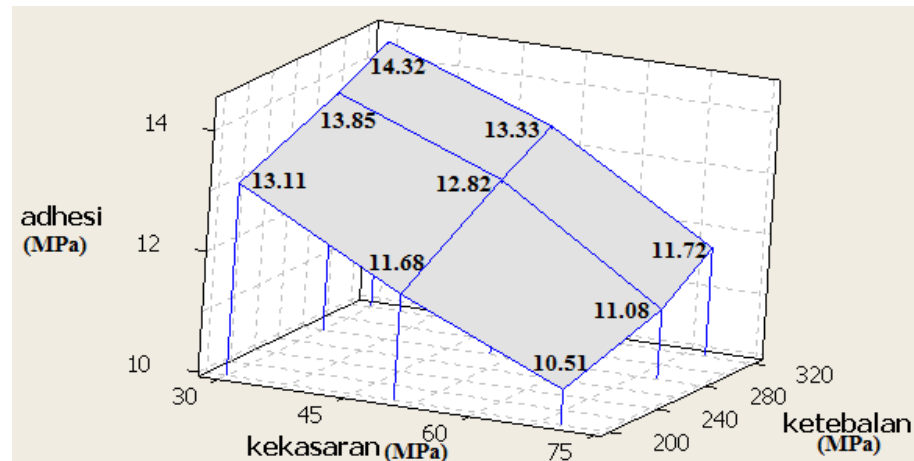

Gambar 2. Grafik 3D Pull off adhesion test

Dari Gambar 3 diperoleh bahwa pengujian yang memiliki daya lekat tertinggi untuk struktur jembatan adalah $13.11 \mathrm{MPa}$ pada kekasaran 30-50 $\mu \mathrm{m}$ dengan ketebalan cat $200 \mu \mathrm{m}$, daya lekat tertinggi untuk industri pengolahan kimia adalah 13.85 MPa pada kekasaran 30-50 $\mu \mathrm{m}$ dengan ketebalan cat $280 \mu \mathrm{m}$, dan daya lekat tertinggi untuk struktur di lingkungan laut adalah 14.32 MPa pada kekasaran 30-50 $\mu \mathrm{m}$ dengan ketebalan cat $320 \mu \mathrm{m}$.

Terjadi penurunan nilai daya lekat karena ketebalan yang rendah, walaupun demikian nilai daya lekat berada di atas standar yaitu $5 \mathrm{MPa}$. Selain itu penurunan daya lekat cat terlihat saat kekasaran semakin tinggi.

Pengamatan secara visual diperlukan untuk mengamati presentase terbentuknya kegagalan adhesi (bagian lapisan cat yang terkelupas seluruhnya dari permukaan substrat) dan kegagalan kohesi (pengelupasan diantara lapisan cat).

Cat epoxy berwarna abu-abu doff, sedangkan cat polyurethane memiliki warna putih glossy Pengamatan dapat dilihat pada cat yang terkelupas saat setelah pengujian apabila terlihat bagian yang berwarna putih glossy maka cat polyurethane mengelupas sebagian, jika terlihat bagian yang berwarna doff maka cat polyurethane mengalami pengelupasan seluruhnya, dan saat terlihat warna abu-abu gelap maka bagian permukaan baja karbon kehilangan lapisan cat polyurethane dan begitu juga cat epoxy. Berikut ini foto makro dari pull of adhesion test.

Terjadinya kegagalan kohesi pada pull of adhesion test ini dikarenakan ikatan adhesi antara cat dan permukaan kasar lebih kuat daripada ikatan kohesi antar cat itu sendiri. Semakin kasar permukaan memiliki ikatan adhesi yang lebih tinggi dibanding permukaan yang memiliki kekasaran lebih rendah.

\section{Hasil Uji homogenitas varian}

Tabel 6. Hasil uji homogenitas varian

\begin{tabular}{cccc}
\hline \hline $\mathrm{F}$ & Df1 & Df2 & Sig. \\
\hline 1.636 & 8 & 18 & .183 \\
\hline \hline
\end{tabular}

Dari tabel 6 pemeriksaan varians beberapa kelompok perlakuan dengan software statistik menunjukkan hasil uji homogenitas yang menampilkan nilai sig sebesar 0.183. Karena nilai sig lebih besar dari taraf signifikan atau alpha
0.05 maka dapat dinyatakan bahwa data sudah memenuhi asumsi homogenitas varians.

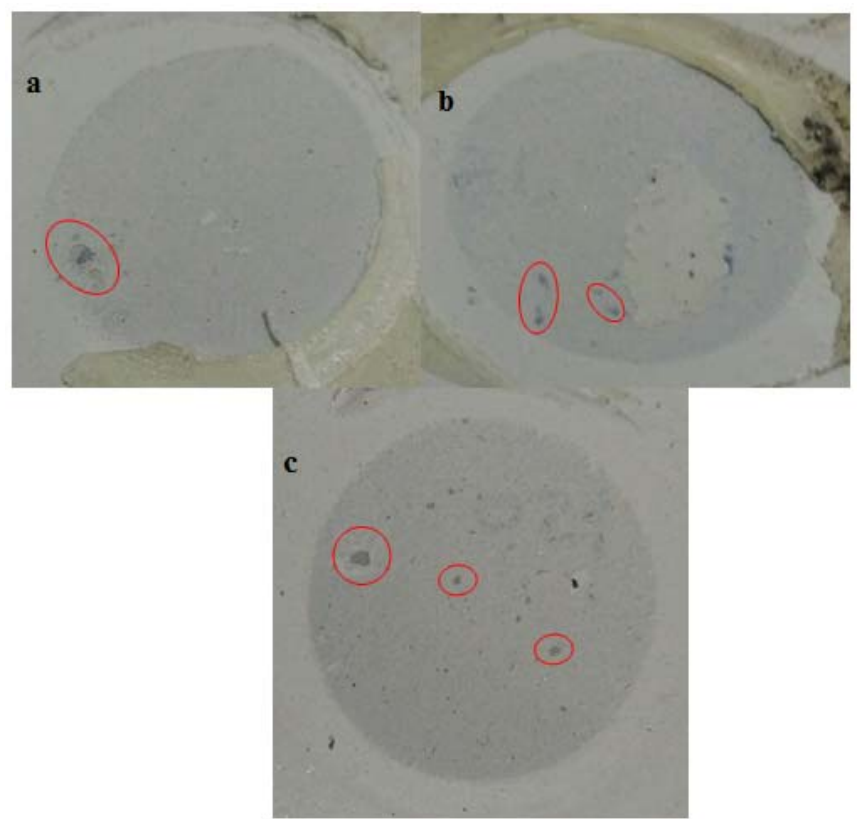

Gambar 3. Foto Makro Hasil Pull off Adhesion Test (a) 30-50 $\mu \mathrm{m}$ (b) $50-70 \mu \mathrm{m}$ (c) $70-85 \mu \mathrm{m}$

Tabel 7. Hasil uji analysis of variance

\begin{tabular}{cccccc}
\hline Source & df & SS & MS & F & Sig. \\
\hline Kekasaran & 2 & 31.949 & 15.974 & 14.767 & .000 \\
Ketebalan & 2 & 8.412 & 4.206 & 3.888 & .039 \\
$\begin{array}{c}\text { Kekasaran* } \\
\text { Ketebalan }\end{array}$ & 4 & 317 & .079 & .073 & .989 \\
Error & 18 & 19.472 & 1.082 & & \\
& & & & & \\
Total & 27 & 4274.151 & & & \\
\hline \hline
\end{tabular}

Dari tabel 7 menunjukkan faktor kekasaran dan ketebalan memiliki pengaruh signifikan. Dilihat dari nilai sig kekasaran sebesar 0.000 dan nilai sig ketebalan sebesar 0.039 lebih kecil dar taraf signifikansi atau $\alpha=0.05$. Maka dinyatakan kekasaran dan ketebalan berpengaruh signifikan terhadap kekuatan adhesi. Akan tetapi jika kekasaran dan ketebalan di interaksikan hasilnya menunjukkan bahwa interaksi antara kekasaran dan ketebalan tidak memiliki pengaruh signifikan terhadap kekuatan adhesi. Dapat dilihat dr nilai sig interkasi kekasaran dan ketebalan sebesar 0.989 yang lebih besar dr 
taraf signifikansi $\alpha=0.05$.

\section{KESIMPULAN DAN SARAN}

\section{A. Kesimpulan}

Setelah melakukan analisa hasil pengujian, adapun kesimpulan yang dapat diambil dari penelitian ini adalah sebagai berikut:

1. Dibuktikan dengan software statistik menunjukkan nilai signifikan kekasaran dan ketebalan lebih kecil dari $\alpha=$ 0.05. Maka dinyatakan kekasaran dan ketebalan berpengaruh signifikan terhadap kekuatan adhesi.

2. Untuk struktur jembatan kekuatan adhesi tertinggi yaitu 13.11 MPa, pada ketebalan cat $200 \mu \mathrm{m}$ dan kekasaaran permukaan 30-50 $\mu \mathrm{m}$. Untuk industri pengolahan kimia kekuaan adhesi tertinggi yaitu $13.85 \mathrm{MPa}$, pada ketebalan cat $280 \mu \mathrm{m}$ dan kekasaaran permukaan 30-50 $\mu \mathrm{m}$. Untuk struktur di lingkungan laut kekuatan adhesi tertinggi yaitu $14.32 \mathrm{MPa}$, pada ketebalan cat $320 \mu \mathrm{m}$ dan kekasaaran permukaan 30-50 $\mu \mathrm{m}$.

3. Proses pengecatan pada pelat baja karbon rendah ukuran $250 \times 250 \times 6 \mathrm{~mm}$ dengan biaya terendah dicapai dengan kekasaran 30-50 $\mu \mathrm{m}$ dan ketebalan cat $200 \mu \mathrm{m}$ sebesar Rp. 8.307. dan biaya tertinggi berada pada kekasaran 70$85 \mu \mathrm{m}$ dan ketebalan $320 \mu \mathrm{m}$ sebesar Rp. 13.645. sehingga semakin tinggi kekasaran dan semakin tebal cat membutuhkan biaya yang semakin tinggi juga.

\section{B. Saran}

Adapun saran penulis untuk penelitian selanjutnya yaitu sebagai berikut:

1. Menambahakan parameter yang berpengaruh dengan kekuatan rekat cat yaitu temperatur pengeringan, material uji, jenis cat, jarak penyemprotan dan perbandingan pelarut.

2. Menganalisa kekuatan rekat cat dengan menambahkan metode Cross cut test.

3. Menambahkan perulangan pada setiap parameter yang diuji.

\section{UCAPAN TERIMA KASIH}

Keberhasilan dalam penyelesaian tugas akhir ini tidak lepas dari berbagai pihak. Oleh karena itu penulis mengucapkan terima kasih kepada $\mathrm{n}$ terima kasih kepada Bapak Sudiyono Kroodiharjo, Bapak Rofiq dan Ibu Diana Sekar Sari yang telah membimbing, Kedua Orang Tua, Adik yang telah memberikan dukungan finansial, dukungan doa, dan semangat serta Evie yang telah memberikan semangat kepada penulis.

\section{DAFTAR PUSTAKA}

[1] ASTM D4541., 1995. Standards Test Method for Pull-Off Strength of Coatings Using Portable Adhesion Testers. America: The United States of America Legally Binding Document.
[2] ASTM D4417., 1999. Standard Test Methods for Field Measurement of Surface Profile of Blast Cleaned Steel. America: The United States of America Legally Binding Document.

[3] Forsgren A., 2006. Corrosion Control Through Organic Coatings. Florida, US: Taylor \& Francis group, CRC.

[4] Gaspersz, Vincent., 1995. Tekinik dan Analisis Dalam Penelitian Percobaan, Jilid 1. Bandung: Tarsito

[5] ISO 12944., 2014. Protect your assets in three easy steps. Tokyo, Japan: Akzo Nobel.

[6] ISO 4624., 2002. Paints and varnishes - Pull-off test for adhesion. Geneva, Switzerland: ISO Copyright Office

[7] Kirono, S., 2011. "Pengaruh Tempering Pada Baja St 37 Yang Mengalami Karburasi Dengan Bahan Padat Terhadap Sifat Mekanis Dan Struktur Mikro". Tugas Akhir Teknik Mesin Universitas Muhammadiyah Jogjakarta, 1-2. Jogjakarta

[8] Trimber K.A. \& Corbett W.D., 2002. SSPC Coating Chapter 7: Inspection. Pennsylvania, USA.

[9] Noor R. \& Ewo T., 2007. "Pengaruh Ketebalan Lapisan Terhadap Daya Lekat Cat". Jurnal Ilmiah Pendidikan Teknik Mesin Universitas Pendidikan Indonesia, Bandung.

[10] NORSOK M-501., 2012. Surface preparation and protective coating. Norwegia : Norwegian Continental Shelf Copyright Office.

[11] Nurmalasari I., 2014. Perhitungan kebutuhan cat. < http://documents.mx/documents/perhitungan-kebutuhan-cat.html> diakses pada 11 Mei 2016.

[12] Schweitzer P. A. 2006. Paint and Coating: Application and Corrosion Resistance. Florida, US: Taylor \& Francis group, CRC.

[13] Setiawan A. 2009. Pengacakan dan Tata Letak Percobaan RAL Model Linier dan Analisis Ragam. Jurnal Ilmiah Universitas Padjajaran, BandungW. D. Doyle, "Magnetization reversal in films with biaxial anisotropy," in 1987 Proc. INTERMAG Conf., 2.2-1-2.2-6.

[14] Tracton A. 2006. Coating Technology Fundamentals, Testing, And Processing Techniques. Florida, US: Taylor \& Francis group, CRC.

[15] Walpole R., 1982. Introduction to Statistics. London, England: Collier Macmillan.

[16] Weldon, Dwight G., 2001. Failure Analysis of Paints and Coating. USA: John Willey \& Sons

[17] Wulandari A., 2015. "Pengaruh Tingkat Cleanliness Dan Roughness Substrat Pada Surface Preparation Terhadap Kekuatan Adhesi Tank Lining". Tugas Akhir Teknik Perkapalan Universitas Diponegoro, Semarang. 